\title{
Feasibility of Bioethanol Production From Lignocellulosic Biomass
}

\author{
Zane Aunina, Institute of Energy Systems and Environment, Riga Technical University, Gatis Bazbauers, Institute \\ of Energy Systems and Environment, Riga Technical University, Karlis Valters, Institute of Energy Systems and \\ Environment, Riga Technical University
}

\begin{abstract}
The objective of the paper is to discuss the potential of cellulosic ethanol production processes and compare them, to find the most appropriate production method for Latvia's situation, to perform theoretical calculations and to determine the potential ethanol price. In addition, price forecasts for future cellulosic and grain ethanol are compared. A feasibility estimate to determine the price of cellulosic ethanol in Latvia, if production were started in 2010, was made. The grain and cellulosic ethanol price comparison (future forecast) was made through to the year 2018.
\end{abstract}

Keywords - biofuel, cellulosic ethanol, woody biomass, economics.

\section{INTRODUCTION}

In the long term, ethanol is one of the most promising biofuels because it can be produced from a large variety of materials, if only they contain simple or complex sugars. For the industrial production of ethanol, mostly sugarcane or starchy feedstock (like corn, potatoes etc.) are used. However, a more promising feedstock - the lignocellulosic biomass can be used. Bioethanol which is produced from cellulosic biomass is called cellulosic ethanol [1].

Ethanol is extensively used in three ways - in medicine (both in drugs, and as a disinfectant), in spirituous liquids, and as biofuel (as pure biofuel or blended in low proportions with fossil fuel gasoline) in motor vehicle internal combustion engines.

\section{ETHANOL CONVERSION METHODS}

There are two primary routes for the production of cellulosic ethanol - biochemical and thermochemical routes:

A. The biochemical conversion process consists of the hydrolysis of pre-treated lignocellulosic feedstock, which relies on the use of enzymes and other microorganisms, or chemicals to destroy structure of the cellulosic chain and to obtain simple sugars, such as glucose. After hydrolysis, sugar fermentation and distillation processes follow.

B. In the thermochemical conversion process route, lignocellulosic feedstock is gasified and synthesis gas (syngas), such as carbon monoxide (CO) and hydrogen $\left(\mathrm{H}_{2}\right)$ is obtained. These gases can further be converted to ethanol through both fermentation and catalytic processes.

\section{A. Biochemical conversion process}

The conversion of lignocellulose to ethanol consists of five main technological processes [2, 3, 4]:

1) Biomass pre-treatment - it is the destruction of lignocellulosic structure and simultaneous lignin separation. Pre-treatment can occur in a physical, biological, chemical or physicochemical way.

2) Hydrolysis - to break down the cellulosic chain into simple sugars, in the presence of enzymes or chemical substances.

3) Fermentation - the process to convert sugars to ethanol, most frequently with the aid of bacteria or yeast strains;

4) Distillation and purification - ethanol separation and purification in order to meet the fuel specifications (properties);

5) Wastewater treatment and co-product utilization.

Biochemical conversation is shown in Figure 1.

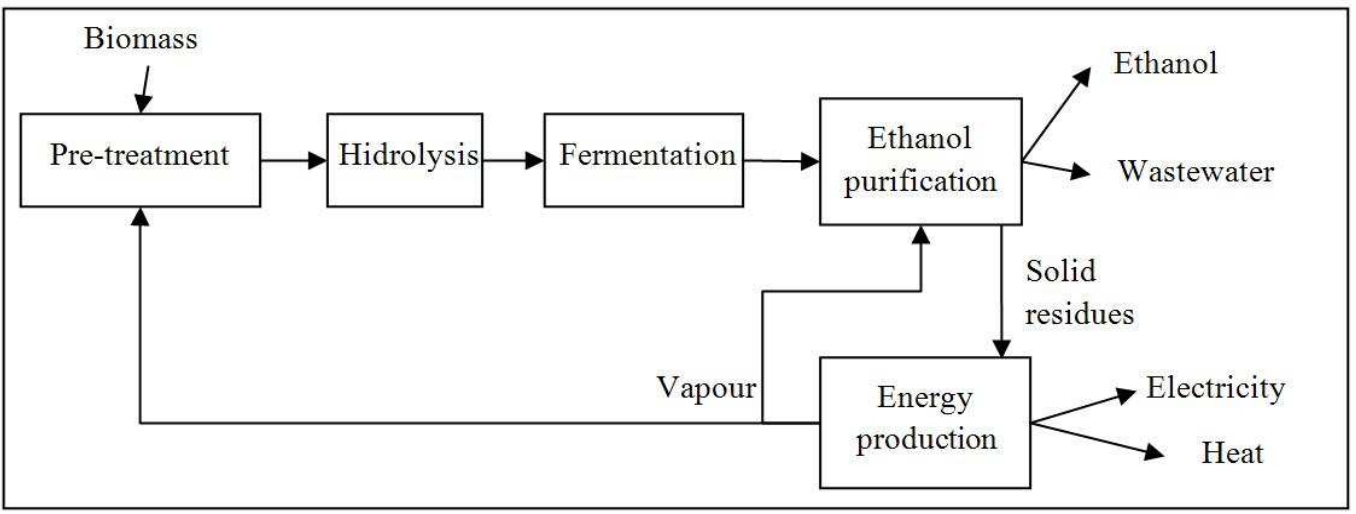

Fig. 1. Schematic ethanol manufacturing from lignocellulosic biomass, via fermentation process [1]. 


\section{B. Thermochemical conversation process.}

This process can be carried out in two ways $[5,6]$ :

1) Through a complex thermochemical and biological system. Gasification, where carbon based molecules are broken apart to access the carbon and carbon monoxide, carbon dioxide and hydrogen are produced. This follows by fermentation where the carbon oxides and hydrogen are converted into ethanol using organisms that consume carbon oxides and produce ethanol and byproducts.

2) Thermochemical process - where, like in point one, biomass is gasified to obtain carbon oxides, followed by catalysis, where gases are converted into ethanol and other higher alcohols with the aid of a catalyst. The process ends with alcohol distillation and purification.

\section{LIGNOCELLULOSIC FEEDSTOCK}

Currently, the production of ethanol is based on the use of raw materials containing starch or sugar - respectively, different types of grains (mostly wheat and rice), corn, potatoes and sugarcane or sugar beet. However, this kind of materials can be used in food production, which means that the increasing demand for ethanol may cause an increase in raw material prices, resulting in a simultaneous ethanol and food price jump [7].

For these reasons scientists have carried out a series of studies and come to discover the broken wood pulp structure, and how to extract the wood sugars, which can be fermented exactly the same way as starch or any simple sugars. The fermented ethanol, because of its properties, is identical to the one obtained from starch or sugar $[7,8,9]$.

Raw materials can be divided into two broad categories:

1. Raw materials that are specifically grown for the needs of bioethanol production, or energy crops. This category may include fast-growing crops like willows and energetic grasses (fast-growing grasses with high yields per hectare, for example, Sweet Clover, Timothy, Lucerne, etc.) [8].

2. Wastes or industrial by-products from a variety of industrial or farm activities. There might be other materials such as forestry products (branches, stumps, etc.), agricultural wastes (straw, green mass of different cultures - e.g., potato and beet tops) and the biodegradable portion of municipal waste (paper, food waste, etc.) $[8,9]$.

Materials with a higher cellulose and hemicellulose content, and lower lignin content have higher ethanol extraction potential. This is explained by the fact that lignin is a lignocellulosic fibrous part which cannot be turned into ethanol.

Raw materials must be chosen by evaluating criteria such as [10]:

- a high level of theoretical ethanol yield from raw materials;

- raw materials or by-products used in other manufacturing sectors - with a higher added value;

- a large amount of available raw materials;

- non-food use;
- biological depleting potential (how easy it is to break down the lignocellulosic fibers).

\section{LIFE CYCLE ANALYSIS}

The product (in this case - cellulosic ethanol) life cycle consists of several stages, starting with the production of raw materials and ending with the management of waste. The lifecycle analysis is an environmental impact analysis of a product throughout its life cycle. Life cycle analysis is described in the whole industrial system, which engages in production, use of the product and waste management.

Cellulosic ethanol environmental impacts of all life-cycle may vary widely, depending on what materials are used in the production, plant geographical location, by-products, resulting in the production process and its utilization possibilities, the chosen production technologies, and, finally, how the obtained biofuel is used (as a fuel to generate energy or as a fuel for car engines) [11].

However, the cellulosic ethanol life cycle consists of five main stages, from biomass production /extraction and transport, followed by bioethanol production, biofuel distribution (delivery to the consumer), and the chain of the life cycle ends with ethanol consumption or use [11].

Despite the many life cycle stages, bioethanol, compared with fossil fuels, has about 20-55\% lower life cycle greenhouse gas emissions and it is a locally sourced fuel, which is an important factor for national economic development and energy independence. Furthermore, the use of bioethanol can contribute to the diversification of the agricultural sector, improve rural economic development, encourage the development of underdeveloped areas, as well as promote environmentally friendly transport, hence improving the air quality in large cities and in other sensitive areas [12].

\section{ECONOMICAL ANALYSIS}

\section{A. Plant modeling}

Drawing from studies and estimates conducted in the pilot station and the first commercial cellulosic ethanol production facilities, cellulosic ethanol production plant economic life provides an average 15 years, but the plant technical lifetime can actually reach up to 20-25 years [13].

The operating expenses of ethanol plants include such cost items as the cost of the biomass and raw materials, their treatment costs, the cost of hydrolysis, fermentation and ethanol purification process, the cost of various energy resources and water, the additional costs involved in ethanol storage, plant maintenance, insurance, taxes, personnel recruitment, loan interest payments, and the other additional costs. Relevant cost items per liter of ethanol are summarized in Table 1 [13].

The cellulosic ethanol price as it could be in Latvia, if ethanol production would commence in the year 2010 is shown in Table 1. 
TABLE I

ADJUSTED COSTS FOR BIOETHANOL PRODUCTION FROM CELLULOSIC FEEDSTOCK IN LATVIA ${ }^{\mathrm{a}}[13]$

\begin{tabular}{|l|l|l|l|}
\hline No & Cost category & \% of total costs & $\begin{array}{l}\text { Costs per liter of ethanol in } \\
\text { Latvian Lats in } \mathbf{2 0 1 0} \\
\left(\mathbf{L V L} \mathbf{L s}_{\mathbf{2 0 1}} / \mathbf{l}_{\text {et }}\right.\end{array}$ \\
\hline 1. & Biomass & $31,96 \%$ & 0,290 \\
\hline 2. & Enzymes & $9,31 \%$ & 0,085 \\
\hline 3. & $\begin{array}{l}\text { Other raw materials (sulfuric acid, lime, } \\
\text { glucose, nutrients) }\end{array}$ & $4,57 \%$ & 0,041 \\
\hline 4. & Waste management & $0,46 \%$ & 0,004 \\
\hline 5. & Electricity & $-3,86 \%$ & -035 \\
\hline 6. & Water & $0,19 \%$ & 0,002 \\
\hline 7. & Labor/supervision & $1,86 \%$ & 0,017 \\
\hline 8. & Maintenance & $6,13 \%$ & 0,056 \\
\hline 9. & Direct overhead & $1,11 \%$ & 0,010 \\
\hline 10. & General overhead & $5,57 \%$ & 0,051 \\
\hline 11. & Insurance and property taxes & $3,06 \%$ & 0,028 \\
\hline & Total cash costs & $\mathbf{6 0 , 3 3 \%}$ & $\mathbf{0 , 5 5}$ \\
\hline 12. & Annualized capital charge & $39,67 \%$ & 0,36 \\
\hline & Total production cost & $\mathbf{1 0 0 , 0 0 \%}$ & $\mathbf{0 , 9 1}$ \\
\hline
\end{tabular}

${ }^{a}$ Cellulosic ethanol costs have been updated from [13] (Soloman et al. 2007) and recalculated using the consumer price index.

${ }^{\mathrm{b}}$ The cost category of electricity is negative, because it is produced in the ethanol station by using combustion by-products (such as lignin, etc.) and excess energy is fed to the network, thereby gaining revenue.

${ }^{\mathrm{c}}$ Annualized capital charge consists of $20 \%$ of the total capital investment, and assuming a $10 \%$ after-tax rate of return on capital.

Further, a cellulose ethanol and grain ethanol price comparison and future forecasts, using the previously obtained results and the forecasts for cellulosic ethanol price of the Netherlands Ministry of Economic Affairs and the grain ethanol price forecasts of the Organisation for Economic Cooperation and Development (OECD) was conducted [15].

The Netherlands Ministry of Economic Affairs expects that the cellulosic ethanol price in Europe will drop in the 33\%
- 40\% range during the years 2010. - 2020. Therefore from this forecast three possible scenarios for a decrease in prices will be considered $-33 \%, 40 \%$ and $60 \%$ from the previously calculated price in the next ten years [14].

Combining the cellulosic ethanol price drop scenarios and the OECD forecasts for grain ethanol prices a graph, shown in Figure 2, was generated.

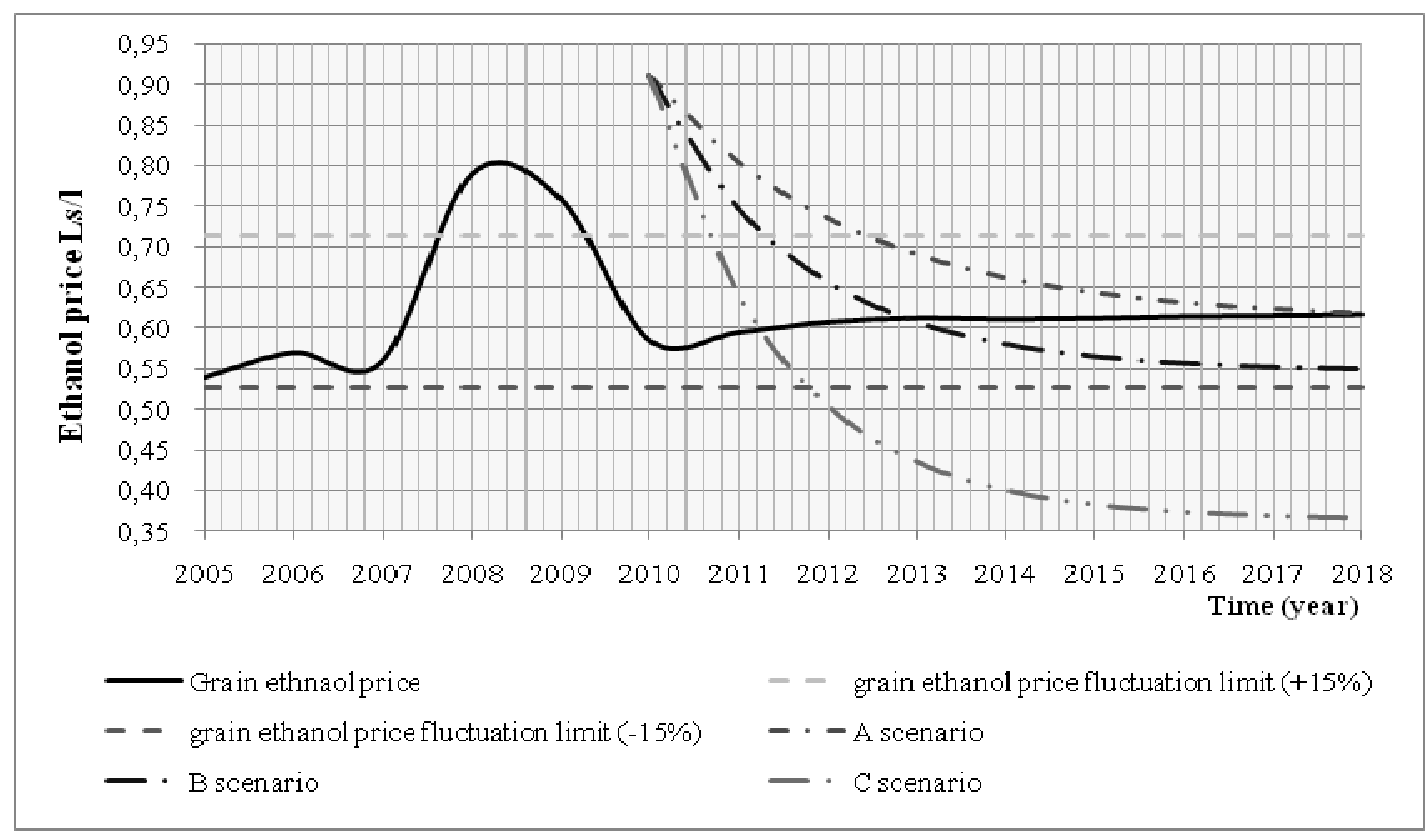

Fig.2. Cellulosic ethanol and grain price scenario comparison - forecasts for the future through 2018 [14, 15]. 
As shown in Figure 2, at Scenario A the cellulosic ethanol price around the year 2018 may already have achieved the expected price of grain ethanol. Thus, after Scenario A grain and cellulosic ethanol prices in 2018 could be at the same level. According to Scenario B, around the year 2013 the price of cellulosic ethanol could reach the price level of grain ethanol and in 2018 it could even be lower by approximately $11 \%$. Scenario B is more optimistic than Scenario A, which is probably the most realistic in forecasting the decreasing price trend. But, according to the most optimistic scenario Scenario C, grain and cellulose ethanol prices could reach the same level already in the year 2011, but by the year 2018, the cellulosic ethanol price might be lower than the projected grain ethanol price by about $40 \%$. It may be concluded that Scenario $\mathrm{C}$ is too optimistic, because in that case in the next two years, a very rapid development of cellulosic ethanol must begin, and substantial resources in research and development, as well as a change in legislation and in the provided support rates for biofuel to promote cellulosic ethanol production should take place. Reality indicates that all these factors are time-intensive and therefore this scenario is only theoretical possible. However in general, Figure 2 shows that future projections are promising, and the cellulosic ethanol price may quite soon be competitive with grain ethanol prices, thereby creating a positive push to the development of bioenergy and the reduction of fossil fuel consumption and the associated greenhouse gas emissions.

\section{B. Measures to achieve price reduction}

In the calculations performed previously, the cellulosic ethanol price was established at Ls 0,91 (Table 1). While price changes were anticipated, the price of grain ethanol for the year 2010 was set at Ls 0,59. Consequently, the price difference draws up to about $35 \%$. This means that the cellulosic ethanol price needs to decrease by $35 \%$ (Ls 0,32), for its production to become economically competitive, compared to grain ethanol. The grain and cellulosic ethanol price comparison in Latvia in 2010 is shown in Figure 3.

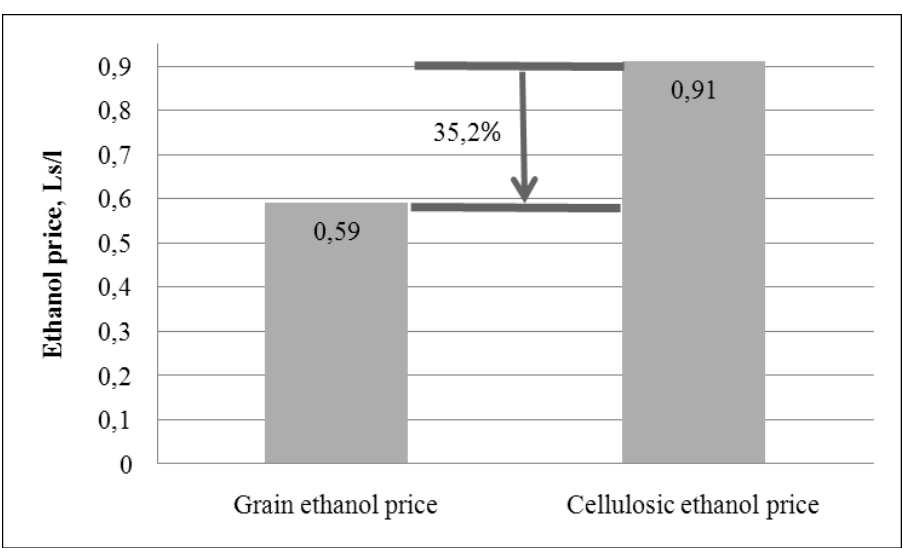

Fig.3. Grain and cellulosic ethanol price comparison in Latvia in 2010.

To achieve a reduction in the cellulosic ethanol price, it is necessary to implement complex price reduction efforts, which would include the following:

1. Capital investment reduction, by involving the cofinancing of European Union's financial instruments, by developing a standardized factory model concept and the mass production of equipment, which would reduce investments in buildings, infrastructure and facilities.

2. Development of enzyme production technologies, because now enzymes are relatively expensive materials, but with the trend of price reduction.

3. It should be considered what type of biomass will be used in production technology, because raw materials can be grown specifically for ethanol production - the energy crops or waste products can be used.

4. Lignocellulosic ethanol industrial by-products would need to be used for energy recovery in order to maximize revenue from by-products and thereby reduce the ethanol price.

5. It is necessary to develop a variety of production technologies in order to diversify the production methods and hence both the equipment and material suppliers, to avoid dependence on any particular country or supplier.

\section{CONCLUSIONS}

It is clear, that in the near future one needs to find a substitute or alternative-renewable fuel for fossil energy, which would be possible to produce in large quantities. Bioethanol is already one of the most common types of biofuels. However, currently it is made from materials that can be used for food production (cereals, potatoes, sugar beet, etc.), so it has initiated extensive studies to obtain ethanol from cellulose-containing materials. The biggest driver for the cellulosic ethanol development is the opportunity to use it as fuel for car engines.

The world's most serious research in the field of cellulosic ethanol production has only recently begun and in Latvia research in this area is quite negligible. Currently, the greatest barriers for the production of cellulosic ethanol on a large scale are significant financial contributions to both the production unit and also the production process. Wherewith, ethanol production, compared to the grain ethanol production, currently is more expensive, and substantial capital investment for construction of a new ethanol plant is needed. In the Latvian situation, political interests which are not prone to the production of alternative resources come up in addition to financial issues.

Regarding the provision of cellulosic ethanol feedstock, the Latvian renewable energy policy currently tends towards supplies from energy crop growing by utilizing financial aid provided by EU funds. But the renewable energy policies in other developed countries are more focused on the simultaneous processes of waste or by-product utilization and energy production, thereby obtaining the maximum positive benefit to the environment, economy and society.

Summarizing the proposed price forecasts, it can be concluded that by initiating cellulosic ethanol production in Latvia already in the year 2010, a relatively profound decline in cellulosic ethanol prices in the next 3-5 years could be expected. Already around the year 2018, cellulosic ethanol production may become economically viable compared to grain ethanol production since the cellulosic ethanol price will 
reach the levels of the grain ethanol prices or may be even lower.

The projected fall in prices can be achieved with such measures as essential reduction of the capital investment part; rapid reduction of raw material costs or the complex price reduction of those two components. One of the instruments to reduce prices includes the financial aid provided by European Union funds for production development, and the other is the use of waste as a feedstock.

\section{REFERENCES}

1. Piccolo C., Bezzo F. A techno-economic comparison between two technologies for bioethanol production from lignocellulose. Biomass and bioenergy 33: 2009. 479-491 p.

2. Eggeman T., Elander RT. Process and economic analysis of pretreatment technologies. Bioresource Technology 96 (2005), 20192025 p.

3. Hamelinck C.N., van Hooijdonk G., Faaij A.P.C. Ethanol from lignocellulosic biomass: techno-economic performance in short-, middleand long-term. Biomass and Bioenergy Vol. 28 (2005). 384-410 p.

4. Mosier N., Wyman C., Dale B., Elander R., Lee Y.Y., Holtzapple M., Ladisch M. Features of promising technologies for pre-treatment of lignocellulosic biomass. Bioresource Technology 96 (2005), 673-686 p.

5. Cellulose ethanol. National Renewable Energy Laboratory. Golden: March 2007.

6. Biofuel technologies. // Syntec Biofuel: http://www.syntecbiofuel.com/ Biofuel_Technologies.php [Accessed 26.01.2010.].
7. Vēvers J. Aktīvāk meklē instrumentus cīnai pret pārtikas cenu kāpumu. Diena, Wednesday, April 16th, 2008.

8. Neimane I., et.al. Energétisko augu audzēšana un izmantošana. Valsts SIA ,Vides projekti”. Riga: 2007, 192 p.

9. Jautājumi un atbildes // LTD „Jaunpagasts Plus”: http://www.jpplus.lv/lv/faq [Accessed 26.11.2009.];

10. Luo L. et al. Biorefining of lignocellulosic feedstock - technical, economic and environmental considerations. Bioresource technology. 2010.

11. Rutz D., Janssen R. BioFuel Technology Handbook. WIP Renewable energies, Germany, München: 2007, 149 p.

12. Bonilla D. Freight Transport and Deployment of Bioenergy in the UK Oxford University Centre for the Environment, UK: 2009, 23 p.

13. Solomon et al. Gain and cellulosic ethanol: History, economics, and energy policy. Biomass \& Bioenergy Vol. 31. 2007, 416-425 p.

14. Bioethanol in Europe. Overview and comparison of production processes. Report. Ministry of Economic Affairs and Ministry of Transport, Public Works and Water Management. The Netherlands, 2008, 63 p.

15. OECD-FAO Agricultural Outlook 2009-2018. // Organization for Economic Co-operation and Development: http://stats.oecd.org/ viewhtml. aspx ?QueryId=20152\&vh=0000\&vf=0\&1\&il=blank\&lang=en. June 2009 [Accessed 30.03.2010].

\section{Corresponding author:}

Zane Aunina, Mg.sc.ing.

Institute of Energy Systems and Environment, Riga Technical University

Address: Kronvalda boulevard 1, LV-1010, Riga, Latvia

Phone: +371 26783867, Fax: +37167623512

E-mail: zane.aunina@rtu.lv

\section{Zane Auniṇa, Gatis Bažbauers, Kārlis Valters. Bioetanola ražošanas iespējas Latvijā no lignocelulozi saturošas biomasas}

Etanols ir viena no daudzsološākajām biodegvielām, jo principā to var iegūt no jebkura materiāla, kas satur vienkāršos vai saliktos cukurus. Industriālai etanola ražošanai lielākoties izmanto cukurniedres vai cieti saturošas izejvielas (labību, kartupel̦us u.c.). Tomēr, kā viena no daudzsološākajām izejvielām tiek lēsta tieši lignocelulozi saturoša biomasa. Bioetanolu, kas iegūts no celulozes biomasas, sauc par celulozes etanolu.

Ĺoti plaši etanols tiek izmantots trīs sektoros - medicīnā (gan zālēs, gan kā dezinfekcijas līdzeklis), alkoholiskajos dzērienos, un kā biodegviela (tīra biodegviela vai maisījumā ar fosilo degvielu) automašīnu iekšdedzes dzinējos.

Celulozes etanola iegūšanu var iedalīt divās lielās kategorijās:

1. Celulozes šķelšanas process, kas sastāv no iepriekšapstrādātu lignocelulozes izejmateriālu hidrolīzes, izmantojot fermentus, lai izjauktu celulozes struktūru un iegūtu vienkāršos cukurus, piemēram, glikozi, kam seko fermentācijas un destilācijas procesi.

2. Gazifikācija - šajā procesā lignocelulozi saturošie izejmateriāli tiek gazificēti un iegūtas tādas gāzes kā oglekla oksīds $(\mathrm{CO})$ un ūdenradis (H $\left.{ }_{2}\right)$. Tālāk šīs divas iegūtās gāzes var tikt pārvērstas etanolā, izmantojot fermentāciju vai ķīmisko katalīzi.

Darbā apskatīta celulozes etanola ražošana, izmantojot šķelšanas procesu, šādā procesu kombinācijā: lignocelulozi saturošu izejvielu priekšapstrāde ar atšķaidītu skābi, kam seko hidrolīze enzīmu klātbūtnē, visbeidzot norit iegūto koksnes cukuru fermentācijas process un etanola attīrīšana.

Pētījuma mērķis bija izvērtēt iespējamos celulozes etanola ražošanas procesus un savstarpēji tos salīdzināt, kā arī veikt teorētiskus aprēḳinus un noteikt iespējamo celulozes etanola cenu. Tika veikts celulozes un graudu etanola cenu salīdzinājums, prognozējot to cenas nākotnē laika periodā līdz 2018. gadam. Tika izstrādāts arī tehniski ekonomiskais pamatojums, lai noteiktu, kāda varētu būt celulozes etanola cena, ja ražošana tiktu uzsākta 2010. gadā.

Apkopojot cenu prognožu rezultātus, secināts, ka, uzsākot celulozes etanola ražošanu Latvijā jau 2010. gadā, tuvāko 3-5 gadu laikā būtu vērojams celulozes etanola cenas straujš kritums. Jau ap 2018. gadu celulozes etanola ražošana var kḷūt ekonomiski pamatota, salīdzinot ar graudu etanola ražošanu, jo ap šo laiku celulozes etanola cena varētu sasniegt graudu etanola cenu vai pat būt zemāka par to.

Зане Ауниня, Гатис Бажбауэрс, Карлис Валтерс. Возможности производства биоэтонола из биомассы, содержащий лигноцеллюлозу в Латвии Этанол является одним из перспективных видов топлива, так как в принципе его можно получить из любого материала, в состав которого входит простой или сложенный сахар. В промышленном производстве этанола в основном используют сахарную свеклу или исходные вещества содержащие сахар (зерновые, картофель и т.д.). Однако одним из перспективнейших сырьем считается биомасса содержащая лигноцеллюлозу. Биоэтанол, полученный из целлюлозы биомассы, называют целлюлозным этанолом.

Очень широко этанол используется в трех секторах - медицина (как в лекарствах, так и как средство дезинфекции), в алкогольных напитках и как биотопливо в автомобильных двигателях внутреннего сгорания (в виде чистого биотоплива или в смеси с фоссильным топливом).

Получение целлюлозного этанола можно разделить на две большие категории:

1. процесс расщепления целлюлозы, который состоит из предварительного гидролиза сырья лигноцеллюлозы, для разрушения структуры целлюлозы и получения простого сахара, например, глюкозы, после которого следует процессы ферментации и дестиляции.

2. Газификация - в данном процессе сырье, содержащее лигноцеллюлозу, газифицируется и получаются такие газы, как оксид углерода (СО) и водород $\left(\mathrm{H}_{2}\right)$.

В работе было рассмотрено производство целлюлозного этанола использую процесс расщепления, при следующей комбинации процессов: предварительная обработка сырья содержащего лигноцеллюлозу разбавленной кислотой, после которой идет гидролиз в присутствии энзимов, и, наконец, происходит процесс ферментации полученного древесного сахара и очистка этанола.

Целью исследования была оценка возможных процессов производства целлюлозного этанола, а так же их сравнение между собой, в том числе произведение теоретических расчетов и определение возможной цены на целлюлозный биоэтанол. Было произведено сравнение будущих цен на зерновой и целлюлозный этанол в период времени до 2018 года. Так же было разработано технически-экономическое обоснование для определения цены на целлюлозный этанол, в случае если бы производство было начато в 2018 году.

Обобщив результаты прогнозов цен, были сделаны выводы, что начав производство целлюлозного этанола в Латвии в 2010 году в ближайшие 3-5 года наблюдалось бы существенное снижение цен целлюлозного этанола. Уже около 2018 года производство целлюлозного этанола могло бы стать экономически обоснованным, если его сравнивать с производством зернового этанола., так как к этому периоду времени цена целлюлозного этанола достигла бы цену зернового этанола или была бы ниже ее. 